\title{
Sid \\ First report of Pepo aphid-borne yellows virus on zucchini in Cote d'Ivoire
}

N. Kone ${ }^{1}$, A. Coulibaly $^{1}$, O. Koita ${ }^{2}$, D. Kone ${ }^{3}$, E.A. Bediako ${ }^{4}$, D. Knierim ${ }^{5}$, W. Menzel ${ }^{5}$ and S. Winter $^{5}$

${ }^{1}$ Institute Polytechnique Rural de Formation et de Recherche Appliquée (IPR-IFRA), Katibougou, BP 06, Mali ; ${ }^{2}$ Laboratory of Applied Molecular Biology, Faculty of Science and Techniques, Bamako, BP E3206, Mali; ${ }^{3}$ University Felix Houphouet Boigny, 22 BP 582 Abidjan 22, Côte d'Ivoire; ${ }^{4}$ University of Cape Coast, Department of Crop Science School of Agriculture, Cape Coast P. O. Box 5007, Ghana; ${ }^{5}$ Leibniz Institute DSMZ - German Collection of Microorganisms and Cell Cultures, Inhoffenstraße 7B, 38124 Braunschweig, Germany

*E-mail: wulf.menzel@dsmz.de

Received: 13 Apr 2015. Published: 31 May 2015. Keywords: PABYV, Cucurbitaceae, Polerovirus

Cucurbits are very important crops for West African farmers, in particular in Côte d'Ivoire, ensuring self-sufficiency and the generation of income. However, plant viral diseases are a major constraint to cucurbit production (Lecoq \& Katis, 2014). During a virus survey in the dry (January to March 2014) and wet (June to August 2014) seasons, about $80 \%$ of cucurbit plants presented virus-like symptoms. A total of 757 leaf samples were collected from cucumber (Cucumis sativus), squash and zucchini (Cucurbita pepo), watermelon (Cirullus lanatus), calabash gourd (Lagenaria siceraria) and melon (Cucumis melo) in 16 regions of Côte d'Ivoire representing six agricultural environments. Samples were selected from leaves with viral symptoms including mosaic, leaf distortion, shoe-string, blister, narrowing, leaf curling and yellowing (Fig. 1). Samples were dried over calcium chloride for later analysis. All samples were tested by double-antibody sandwich-ELISA for Cucumber mosaic virus (CMV), Moroccan watermelon mosaic virus (MWMV), Papaya ringspot virus (PRSV), Watermelon mosaic virus (WMV) and Zucchini yellow mosaic virus (ZYMV) with antisera from DSMZ (Braunschweig, Germany). A total of 399 samples tested positive in ELISA for CMV, PRSV and ZYMV in either single or mixed infections. To check for species of the genus Polerovirus (family Luteoviridae) that are reported to occur frequently in mixed infections with other aphid-borne viruses, RT-PCR screening was done (Knierim et al., 2013; Knierim et al., 2014). Samples totalling 68 representative for the growing regions, seasons and crops were selected. Total RNA was extracted (QIAGEN RNeasy kit) from the dried leaf material and screened by RT-PCR with the universal polerovirus primer pair Gen1 and Gen2 in combination with an internal control (Knierim et al., 2013).

The expected $325 \mathrm{bp}$ dsDNA band indicative of polerovirus presence was amplified from 13 samples and subsequently sequenced. Sequences analysis revealed that all sequences shared $93.8 \%$ to $99.6 \%$ nt identity with one another and subsequent BLAST analysis of each sequence against GenBank confirmed close identity to Pepo aphid-borne yellows virus (PABYV) isolates from Mali (95-97\%; KF427698-KF427700) and to
PABYV isolates from South Africa (93-97\%; KJ789897, KJ789900, KJ789902-KJ789904 and KJ789911). Of the 13 samples that tested positive for PABYV, all were from zucchini and were found in the locations Agokro, Dabou, Daoukro, Divo, Duekoue, Korhogo, Kpokhankro, Man, Songo-te and Tombokaha. We also demonstrated the existence of PABYV in the dry season (eight samples) and wet seasons (eight samples). For four of the 13 PABYV samples, longer sequence fragments (1376 nts) were obtained with another universal polerovirus primer pair (Knierim et al., 2014) and sequence analysis confirmed the first results (GenBank Accession Nos. KR054131-KR054134). Other cucurbitinfecting polerovirus species were not detected during this study.

This is the first report of PABYV from Côte d'Ivoire and the virus is now reported from three countries in Africa (Côte d'Ivoire, Mali and South Africa) since its first description in 2008. It seems to be widely distributed in Côte d'Ivoire, occurring in dry and in wet season crops. Although PABYV was only found in mixed infections in this study and the direct impact on the yield is not known, it should be considered in strategies to manage virus diseases particularly when zucchini is cultivated.

\section{References}

Knierim D, Tsai WS, Kenyon L, 2013. Analysis of sequences from field samples reveals the presence of the recently described pepper vein yellows virus (genus Polerovirus) in six additional countries. Archives of Virology 158, 1337-1341. http://dx.doi.org/10.1007/s00705-012-1598-y

Knierim D, Tsai WS, Maiss E, Kenyon L, 2014. Molecular diversity of poleroviruses infecting cucurbit crops in four countries reveals the presence of members of six distinct species. Archives of Virology 159, 1459-1465. http://dx.doi.org/10.1007/s00705-013-1939-5

Lecoq H, Katis N, 2014. Control of cucurbit viruses. Advances in Virus Research 90, 255-296.

http://dx.doi.org/10.1016/B978-0-12-801246-8.00005-6

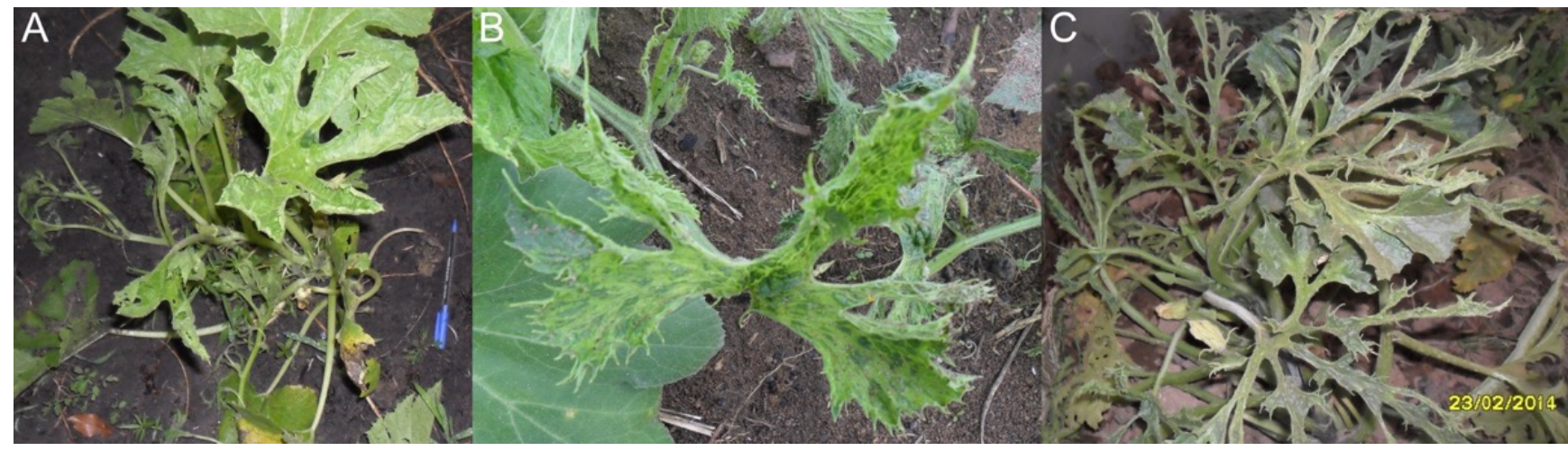

Figure 1

To cite this report: Kone N, Coulibaly A, Koita O, Kone D, Bediako EA, Knierim D, Menzel W, Winter S, 2015. First report of Pepo aphidborne yellows virus on zucchini in Cote d'Ivoire. New Disease Reports 31, 27. http://dx.doi.org/10.5197/j.2044-0588.2015.031.027 (c) 2015 The Authors This report was published on-line at www.ndrs.org.uk where high quality versions of the figures can be found. 